\title{
Recent changes in MBBS curriculum in psychiatry in Bangladesh: a call for attention
}

\author{
Susmita Roy, ${ }^{1}$ SM Yasir Arafat ${ }^{2}$ \\ ${ }^{1}$ Professor, Department of Psychiatry, Jalalabad Ragib Rabeya Medical College, Sylhet, Bangladesh; ${ }^{2}$ Assistant Professor, \\ Department of Psychiatry, Enam Medical College and Hospital, Dhaka, Bangladesh.
}

\section{Article info}

Received

Accepted

Number of tables

Number of refs
$01 \mathrm{Apr}, 2020$
07 Jul, 2020
04
03

\author{
Correspondence \\ Susmita Roy, \\ Mobile: +8801711459277 \\ E-mail:susmita07@hotmail.com
}

Bang J Psychiatry 2018;32(2): 24-25
There has been some remarkable changes in the assessment system of the subject psychiatry from 2002 to 2012 bachelor of medicine, bachelor of surgery (MBBS) curriculum. ${ }^{1,2}$ In 2012 MBBS curriculum in Bangladesh, psychiatry learning and assessment system has been grossly ignored. Though in the curriculum it was clearly mentioned that, an MBBS student must diagnose, manage and refer specific psychiatric disorders, the objective would not accomplish devoid of proper assessment system. In medical education, learning of a subject is not possible without proper assessment in summative examination both in written and clinical examination. ${ }^{2}$ Detailed evaluation revealed that in the current curriculum there is no ward placement in $4^{\text {th }}$ phase $\left(5^{\text {th }}\right.$ Year). Furthermore there is no specific marks distribution in written, no objective structured practical examination (OSPE) station, no short case, no long case and no specific examiner of psychiatry in oral examination. As a result a student can totally escape the entire subject. ${ }^{2}$ The significant comparison between 2002 and 2012 curriculum, drawback of current curriculum and our proposal for upgrading the current curriculum are given below. ${ }^{1,2}$

Comparison of 2002 and 2012 Curriculum

Table 1: Comparison of ward placement of psychiatry ${ }^{1,2}$

\begin{tabular}{lcc}
\hline Ward placement & 2002 & 2012 \\
\hline $4^{\text {th }}$ year & 3 weeks & 3 weeks \\
$5^{\text {th }}$ year & 1 week & No \\
Block posting & 1 week & 3 days \\
\hline
\end{tabular}

Table 2: Comparison of marks and questions distribution of medicine paper II of final professional MBBS examination $^{1,2}$

\begin{tabular}{|c|c|c|}
\hline Type & 2002 & 2012 \\
\hline $\begin{array}{l}\text { Marks distribution } \\
\text { (total 100) }\end{array}$ & $\begin{array}{l}\text { Paediatrics (35), } \\
\text { psychiatry and dermatology (35), } \\
\left(\mathrm{MCQ}^{\star} 20, \mathrm{FA}^{*} 10\right)\end{array}$ & $\begin{array}{l}\text { Paediatrics (35), } \\
\text { internal medicine and allied (35), } \\
\left(\mathrm{MCQ}^{*} 20, \mathrm{FA}^{*} 10\right)\end{array}$ \\
\hline $\begin{array}{l}\text { Questions } \\
\text { distribution }\end{array}$ & $\begin{array}{c}\text { Paediatrics } \\
\text { (SAQ 7; } 5 \text { marks each), } \\
\text { psychiatry and dermatology (SAQ 7; } \\
5 \text { marks each) }\end{array}$ & $\begin{array}{c}\text { Paediatrics } \\
\text { (SAQ 10; } 3.5 \text { marks each), } \\
\text { internal medicine and allied (SAQ } \\
7 ; 5 \text { marks each) }\end{array}$ \\
\hline
\end{tabular}

*MCQ: Multiple choice question, FA: Formative assessment, SAQ: Short answer question

Table 3: Comparison of marks distribution of OSPE, oral and clinical of medicine final professional MBBS examination (Total 300) $)^{1,2}$

\begin{tabular}{lcc}
\hline Type & 2002 & 2012 \\
\hline OSPE marks & 100 & 50 \\
Oral examination marks & 100 & 150 \\
Clinical & 100 (one long case; 50 and two & short cases; 25 for each) \\
(long and short cases) & she (one long case; 50 and five \\
\hline
\end{tabular}


Table 4: Comparison of OSPE stations, boards and examiners distribution of medicine final professional MBBS examination $^{1,2}$

\begin{tabular}{lcc}
\hline Type & 2002 & 2012 \\
\hline Total OSPE station & 10 & 10 \\
OSPE station for psychiatry & 1 & 0 \\
Oral examination boards & 2 (four examiners) & 3 (six examiners) \\
Examiners distribution in & Two internal medicine, one paediatrics, & Three internal medicine, two paediatrics, \\
oral examination board & one psychiatry or dermatology & one allied or subspecialty \\
\hline
\end{tabular}

\section{Drawback of current (2012) curriculum}

There is no specific distribution of marks and questions (including SAQ and $M C Q$ ) in medicine paper II for psychiatry. Group A contains eight questions and students have to answer seven questions. $^{2}$ If the group contains only one question from psychiatry, then there might have chances to escape the psychiatry totally. There is no specific OSPE station and shirt case of psychiatry. ${ }^{2}$ Moreover, there is no allocation for a specific examiner from psychiatry even two more examiners have been allocated in the current curriculum. ${ }^{2}$ The situation can bolster the possibilities of escaping psychiatry as a whole.

\section{Proposal}

To cover up the subject psychiatry and make the current curriculum more logical, need based and for improvement of problem area, there are some proposals for modification of learning system and final professional examination of medicine.

- At least one week ward placement of psychiatry in $4^{\text {th }}$ phase $\left(5^{\text {th }}\right.$ year $)$ along with 3 weeks ward placement in $3^{\text {th }}$ phase $\left(4^{\text {th }}\right.$ year $)$ is recommended.

- Medicine paper-II group A portion suppose to contain 4 questions from psychiatry (currently, there is no specific number distribution for Psychiatry).

- One OSPE station for psychiatry is recommended (currently there is no OSPE station for psychiatry).
- One short case for psychiatry is recommended (currently there is no short case for psychiatry).

- One examiner from psychiatry is recommended for viva board.

Psychiatry has been considered as an under focused branch of medicine in Bangladesh. It has a poor physician-patient ratio that will be worse in case of psychiatry. The current MBBS curriculum has put little attention on psychiatry. ${ }^{3}$ Although, the curriculum plays a key role to develop manpower as per the need, in the recent situation it has been heading towards the wrong direction in Bangladesh as there is mounting burden of mental disorders. The article was aimed to draw proper attention of the psychiatrists, medical education experts and all other stake-holders of Bangladesh to take necessary steps to deal with the further challenges of mental health in the country.

\section{References}

1. Bangladesh Medical and Dental Council. 2002. MBBS Curriculum Update - 2002. https://www.bmdc.org.bd/ curriculum-2002

2. Bangladesh Medical and Dental Council. 2012. MBBS Curriculum Update - 2012. http://www.mmc.gov.bd/ downloadable\%20file/new_curriculum/ The \%20updated\%20MBBS\%20Curriculum\%202012.pdf

3. Arafat SMY. The current status of psychiatric education in Bangladesh. Asian J Psychiatr 2020;52:102108. DOI: 10.1016/j.ajp.2020.102108 